\title{
THE NEW CORONAVIRUS AND THE CONSEQUENCES IN THE MENTAL HEALTH OF HEALTH PROFESSIONALS INVOLVED IN THEIR COURSE
}

\author{
O NOVO CORONAVÍRUS E AS CONSEQUÊNCIAS NA SAÚDE MENTAL DOS PROFISSIONAIS DE SAÚDE \\ ENVOLVIDOS EM SEU ENFRENTAMENTO \\ EL NUEVO CORONAVIRUS Y LAS CONSECUENCIAS EN LA SALUD MENTAL DE LOS PROFESIONALES DE LA \\ SALUD INVOLUCRADOS EN SU AFRONTAMIENTO
}

\section{Érika da Silva Maciel}

Post-doctorate in Science by the Department of Clinical Medicine (FCM-USP). Professor at Universidade Federal do Tocantins (UFT), Miracema, Tocantins. erikasmaciel@gmail.com.

0000-0002-9836-7665

\section{Marcele Gotardelo}

Master's student in the Graduate Program in Teaching in Science and Health (PPGECS) at Universidade Federal do Tocantins (UFTPostgraduate in Intensive Care and Active Methodologies and Innovative Practices. Graduation in Nursing. marcelegotardelo@gmail.com.

0000-0001-7179-7537

\section{Allana Lima Moreira Rodrigues}

Master's student in the Graduate Program in Teaching in Science and Health (PPGECS) at Universidade Federal do Tocantins (UFT). Postgraduate in Public Health. Graduation in Nursing. lana.moreiira@gmail.com.

0000-0001-8036-7280

\section{Fernando Rodrigues Peixoto Quaresma}

Doctor of Health Sciences (FMABC). Professor in the Nursing course at Universidade Federal do Tocantins (UFT) an in the Graduate Program in Teaching in Science and Health (PPGECS) at Universidade Federal do Tocantins (UFT). ferodriguesto@gmail.com.

\section{0-0001-8407-0310}

\section{Aldair Martins Barasuol}

Master in Science and Health Teaching by Universidade Federal do Tocantins (UFT), Palmas/TO. Graduation in Nursing. aldair.barasuol@mail.uft.edu.br.

0000-0002-7122-4648

\begin{abstract}
Ladislau Ribeiro do Nascimento
Doctor in Social Psychology from Universidade de São Paulo (USP). Professor of the Psychology Course and the Graduate Program in Teaching in Science and Health at Universidade Federal do Tocantins (UFT). ladislaunascimento@uft.edu.br.
\end{abstract}

\section{0-0002-6980-706X}

Mailing Address: Universidade Federal do Tocantins, Coordenação de Enfermagem. Avenida NS 15, Quadra 109 Norte Plano Diretor Norte 77000000 - Palmas, TO - Brasil - Caixa-postal: 77001090

\section{Received: 10.12.2020.}

Accepted: 11.20.2020.

Published: 01.01.2021.

\begin{abstract}
:
The disease pandemic caused by the new Coronavirus - SARS-Cov-2 is characterized as one of the biggest international public health problems in recent decades. This study aimed to perform a narrative review of the evidence described on the impact on mental health of health professionals who work in care practice related to Covid-19. The articles showed that the problems faced by health professionals during the pandemic can lead to exhaustion of the team, physical and mental exhaustion, contributing to the development of psychological problems.
\end{abstract}

KEYWORDS: Covid-19; Mental health; Health professionals.

\section{Introduction}

COVID-19, a disease caused by the new Coronavirus (SARS-Cov-2), was identified in December 2019 in the city of Wuhan, capital of the province of Central China. The virus has a high potential for contagion in exponential numbers and its universal transmission has been recognized by the World Health Organization (WHO) as a pandemic (VASCONCELOS et al., 2020). The COVID-19 pandemic stands out as one of the biggest 
international public health problems in recent decades, reaching the world at a speed never seen before (WHO, 2020).

Symptoms of the disease often involve coughing, fever and breathing difficulties that can lead to death. The considerable number of cases requiring hospital intervention, including care in the intensive care unit, as well as the lack of effective and safe pharmacological treatment, has raised great concern about the crisis in health systems in different countries (Schmidt et al., 2020).

The disease has had a profound global impact, becoming the most severe viral respiratory syndrome since the H1N1 pandemic (Spanish flu) in 1918, thereby, constituting a public health emergency of international concern by the World Health Organization (WHO) (Felipe Ornell et al., 2020).

The number of new cases and deaths resulting from the Coronavirus is impossible to be accurately expressed, as its growth happens exponentially, which can lead to the depletion of hospital beds in Intensive Care Units (ICU) and the collapse of health services worldwide (ZHOU et al., 2020). In Brazil, the rates found at the beginning of June 2020 already placed the country in second place in relation to the number of infected, behind only the United States of America (USA). The number of people affected by the disease grows every day, without scientific perspectives that envision its end (Brasil, 2020; Brunaromero \& Carciofi, 2020; Holanda, 2020; Zhou et al., 2020).

The high number of infected people and the mortality rate brought insecurity and fear to the population, causing psychological and social consequences that affect the mobility capacity of the whole society. The situation was accentuated due to the lack of control mechanisms (Brooks et al., 2020).

These uncertainties bring problems in several areas, directly affecting the daily life and mental health of individuals, as well as health professionals who are working directly or indirectly in coping with the disease (Brooks et al., 2020; Miranda et al., 2020; Schmidt et al., 2020a). In addition to fear and the feeling of insecurity, other manifestations of mental illness and psychosocial suffering stand out, such as depressive episodes, anxiety, sleep disorders, intensification of interpersonal conflicts, panic disorders, anger, insomnia, alcohol abuse and other drugs, suicidal thoughts, suicides and stress (Duan; Zhu, 2020).

The lack of a vaccine against the new Coronavirus has reinforced among health professionals the importance of adopting measures to prevent infection, such as the use of Personal Protective Equipment (PPE) and constant hand hygiene in the care of infected 
patients or not by the virus, in order to reduce the negative impacts of this situation (Holanda, 2020).

Associated with this, the pandemic brings with it an extra problem for the mental health of doctors, nurses and nursing technicians. As they work directly in the care of patients and are under pressure, these professionals are vulnerable to mental illness, due to the relentless and incessant fight against the disease, allowing the manifestation of disorders associated with fear, stress and anxiety. In addition, many health professionals suffer as a result of prejudice and stigmatization associated with the fact that they deal daily with infected people or who are suspected of being infected. (Schmidt et al., 2020).

Thus, this study aimed to carry out a narrative review of the evidence described on what the consequences of this pandemic are on the mental health of health professionals who work facing the new Coronavirus, in order to list the main problems found.

\section{Materials and methods}

This study is descriptive through a narrative review of the literature.

The databases used to search for articles were: Scientific Electronic Library Online (Scielo), Latin American and Caribbean Literature in Health Sciences (LILACS) and PubMed ${ }^{\circledR}$ - National Library of Medicine $(\mathrm{NIH})$. The research was mediated by the following Health Sciences Descriptors (DeCS): "coronavírus", "saúde mental" and "profissionais da saúde" in Portuguese and "coronavirus", "mental health" and "health professional", in English.

Original articles published in primary studies during the year 2020 conducted with health professionals were considered. Abstracts, recommendations and experience reports were excluded from the study, as well as those found in duplicate in the databases consulted. The titles and abstracts of all articles identified in the electronic search were reviewed. The eligible studies according to the described criteria were obtained in full and, based on this action, a list of articles was prepared for analysis.

A total of 69 abstracts were identified in the databases. After reading the titles and abstracts, 52 studies were excluded, totaling 14 articles reviewed in full (Figure 1).

Figure 1 Flowchart containing the study selection process. 

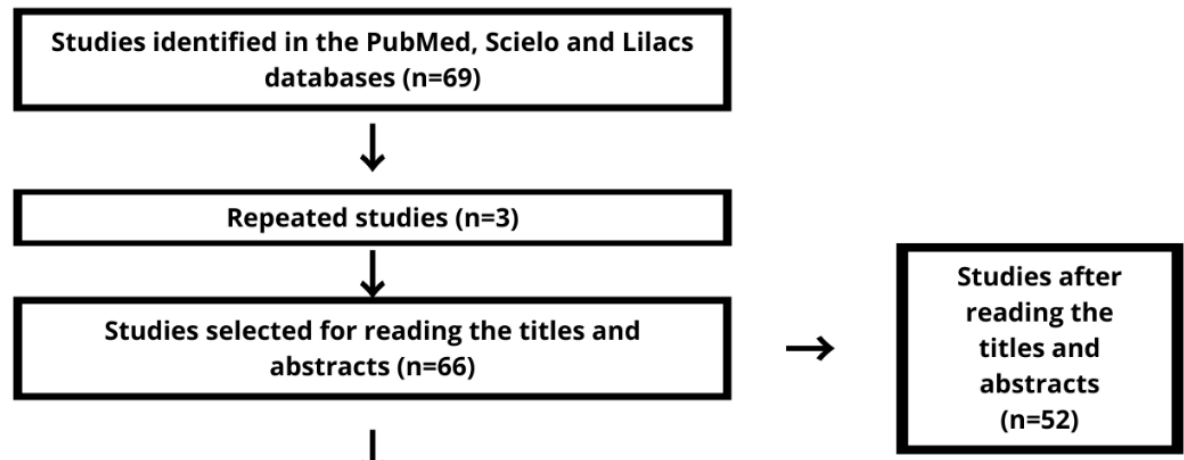

Eligible studies and read in full $(n=14)$

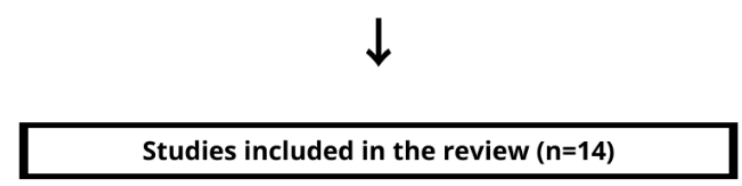

Table 1 presents the main characteristics of the articles that bring results of studies on the impact of the new coronavirus pandemic on the mental health of health professionals. Of the 14 selected works, 13 were found in the English language and translated into Portuguese.

\section{Results}

Most of the studies included have literature review designs, some with metaanalysis. There are also studies with primary data, and the countries of origin of the studies are: Germany, Brazil, Canada, China, United States, England, Italy and Ireland. The analyzed studies demonstrated several psychological responses related to quarantine and coping with the pandemic, including anxiety, stress, depression, insomnia, fear and psychotic disorder (Table 1).

Table 1 Author, title according to the language in which it was published, type of study and main results

\begin{tabular}{|c|l|l|l|}
\hline AUTHOR & \multicolumn{1}{|c|}{ TITLE } & \multicolumn{1}{|c|}{ TYPE OF STUDY } & \multicolumn{1}{c|}{ MAIN RESULTS } \\
\hline NETO, M. R. & $\begin{array}{l}\text { When health } \\
\text { professionals } \\
\text { L. et al. 2020. } \\
\text { look death in the } \\
\text { eye: the mental }\end{array}$ & $\begin{array}{l}\text { Review in the } \\
\text { electronic databases } \\
\text { Scopus and Embase. }\end{array}$ & $\begin{array}{l}\text { The authors describe various psychiatric symptoms } \\
\text { and diseases observed in health professionals from a } \\
\text { collection of articles. }\end{array}$ \\
\hline
\end{tabular}




\begin{tabular}{|c|c|c|c|}
\hline & $\begin{array}{l}\text { health of } \\
\text { professionals } \\
\text { who deal daily } \\
\text { with the } 2019 \\
\text { coronavirus } \\
\text { outbreak. }\end{array}$ & & \\
\hline $\begin{array}{l}\text { EL-HAGE, W. } \\
\text { et al. } 2020 .\end{array}$ & $\begin{array}{l}\text { Health } \\
\text { professionals } \\
\text { facing the } \\
\text { coronavirus } \\
\text { disease } 2019 \\
\text { (COVID-19) } \\
\text { pandemic: What } \\
\text { are the mental } \\
\text { health risks? }\end{array}$ & $\begin{array}{l}\text { International } \\
\text { literature review, } \\
\text { considering } r \text { data } \\
\text { from } r \text { previous } \\
\text { epidemics (SARS- } \\
\text { CoV-1, H1N1) and } \\
\text { more recent data } \\
\text { regarding COVID-19. }\end{array}$ & $\begin{array}{l}\text { The authors report that organizational factors can be } \\
\text { a source of stress: lack of personal protective } \\
\text { equipment, lack of communication, lack of care } \\
\text { materials, interruption of family and social life. Other } \\
\text { risk factors are identified as lack of support, fear of } \\
\text { infecting a loved one, isolation or social stigma and } \\
\text { high level of stress at work. }\end{array}$ \\
\hline $\begin{array}{l}\text { ROHR, S. et } \\
\text { al. } 2020\end{array}$ & $\begin{array}{l}\text { Psychosocial } \\
\text { Impact of } \\
\text { Quarantine } \\
\text { Measures During } \\
\text { Serious } \\
\text { Coronavirus } \\
\text { Outbreaks: A } \\
\text { Rapid Review } \\
\end{array}$ & $\begin{array}{l}\text { Literature review for } \\
\text { studies related to } \\
\text { SARS-CoV and } \\
\text { MERS-CoV } \\
\text { outbreaks. }\end{array}$ & $\begin{array}{l}\text { Quarantine measures during severe coronavirus } \\
\text { outbreaks have extensive negative consequences for } \\
\text { mental health. Prevention and intervention } \\
\text { approaches to mitigate the psychosocial impact must } \\
\text { be an integral component of crisis response during } \\
\text { pandemic conditions. }\end{array}$ \\
\hline $\begin{array}{l}\text { SIMONELLI, } \\
\text { C. et al. } 2020\end{array}$ & $\begin{array}{l}\text { The } \\
\text { psychological } \\
\text { impact of a } \\
\text { pandemic } \\
\text { outbreak on } \\
\text { medical staff - } \\
\text { Literature review }\end{array}$ & $\begin{array}{l}\text { Literature review on } \\
\text { the psychological } \\
\text { impact of a } \\
\text { pandemic outbreak } \\
\text { on the medical team. }\end{array}$ & $\begin{array}{l}\text { The authors describe the evidence for the short and } \\
\text { long-term impact of the epidemic on the mental } \\
\text { health of medical teams. Direct exposure to affected } \\
\text { patients, risk of contagion, subjective perception of } \\
\text { their medical condition as being isolated or } \\
\text { quarantined, all constitute risk factors for mental } \\
\text { symptoms, such as depression, anxiety and post- } \\
\text { trauma. }\end{array}$ \\
\hline $\begin{array}{l}\text { BOHLKEN, J. } \\
\text { et al. } 2020\end{array}$ & $\begin{array}{l}\text { COVID-19 } \\
\text { Pandemic: Stress } \\
\text { Experience of } \\
\text { Healthcare } \\
\text { Workers - A Short } \\
\text { Current Review }\end{array}$ & $\begin{array}{l}\text { Bibliographic review } \\
\text { using the terms } \\
\text { "COVID-19", "stress", } \\
\text { "mental health", } \\
\text { "health } \\
\text { professional", } \\
\text { "team", "psychiatry". }\end{array}$ & $\begin{array}{l}\text { The Patient Health Questionnaire } 9 \text { (PHQ9), the } \\
\text { Anxiety Self-Assessment Scale (SAS) and the Impact } \\
\text { of Event Scale (IES-R) were the test instruments used. } \\
\text { Extensive tension has been reported due to the } \\
\text { experience of stress, as well as symptoms of } \\
\text { depression and anxiety. The severity of mental } \\
\text { symptoms was influenced by age, sex, occupation, } \\
\text { specialization, type of activities performed and } \\
\text { proximity to COVID-19 patients. }\end{array}$ \\
\hline $\begin{array}{l}\text { KISELY, L. et } \\
\text { al. } 2020\end{array}$ & $\begin{array}{l}\text { Occurrence, } \\
\text { prevention, and } \\
\text { management of } \\
\text { the psychological } \\
\text { effects of } \\
\text { emerging virus } \\
\text { outbreaks on } \\
\text { healthcare }\end{array}$ & $\begin{array}{l}\text { Review and meta- } \\
\text { analysis. }\end{array}$ & $\begin{array}{l}\text { The team in contact with the affected patients had } \\
\text { higher levels of acute or post-traumatic stress and } \\
\text { psychological distress. Risk factors for psychological } \\
\text { distress include being younger, being the father of } \\
\text { dependent children or having an infected family } \\
\text { member. Longer quarantine, lack of practical support } \\
\text { and stigma also contributed. Clear communication, } \\
\text { access to adequate personal protection, adequate rest }\end{array}$ \\
\hline
\end{tabular}




\begin{tabular}{|c|c|c|c|}
\hline & $\begin{array}{l}\text { workers: rapid } \\
\text { review and meta- } \\
\text { analysis. }\end{array}$ & & $\begin{array}{l}\text { and practical and psychological support were } \\
\text { associated with reduced morbidity. }\end{array}$ \\
\hline $\begin{array}{l}\text { ORNELL, F. } \\
\text { et al. } 2020\end{array}$ & $\begin{array}{l}\text { The impact of the } \\
\text { COVID-19 } \\
\text { pandemic on the } \\
\text { mental health of } \\
\text { healthcare } \\
\text { professionals. }\end{array}$ & Literature review. & $\begin{array}{l}\text { The authors address the consequences observed after } \\
\text { the latest pandemics (SARS and MERS) and highlight } \\
\text { concepts such as vicarious trauma or secondary } \\
\text { traumatic stress, in addition to highlighting the use of } \\
\text { screening instruments and interventions for } \\
\text { psychological / psychiatric care. }\end{array}$ \\
\hline $\begin{array}{l}\text { SCHMIDT, B } \\
\text { et al, } 2020\end{array}$ & \begin{tabular}{|l|} 
Saúde mental e \\
intervenções \\
psicológicas \\
dianter da \\
pandemia do \\
novo Coronavírus \\
(COVID-19)
\end{tabular} & Literature review. & $\begin{array}{l}\text { The authors describe emotional aspects and } \\
\text { psychotherapeutic interventions aimed at the general } \\
\text { population and health professionals in the context of } \\
\text { the pandemic. }\end{array}$ \\
\hline $\begin{array}{l}\text { PETZOL, M. } \\
\text { B.; PLAG, J.; } \\
\text { STROLE, A. } \\
2020\end{array}$ & $\begin{array}{l}\text { Dealing with } \\
\text { psychological } \\
\text { distress by } \\
\text { healthcare } \\
\text { professionals } \\
\text { during the } \\
\text { COVID-19 } \\
\text { pandemia }\end{array}$ & $\begin{array}{l}\text { The article } \\
\text { summarizes the } \\
\text { recommendations of } \\
\text { WHO and the Inter- } \\
\text { Agency Standing } \\
\text { Committee (IASC). }\end{array}$ & $\begin{array}{l}\text { The article provides the first indications of what health } \\
\text { professionals and their managers can do to reduce } \\
\text { psychological stress. The control of stress and violent } \\
\text { emotions, social support, the maintenance of basic } \\
\text { needs and self-care play a central role. }\end{array}$ \\
\hline $\begin{array}{l}\text { HUANG, J. Z. } \\
\text { et al. } 2020\end{array}$ & $\begin{array}{l}\text { Mental health } \\
\text { survey of medical } \\
\text { staff in a tertiary } \\
\text { infectious disease } \\
\text { hospital for } \\
\text { COVID-19 }\end{array}$ & $\begin{array}{l}\text { Cross-sectional } \\
\text { study using Cluster } \\
\text { sampling. }\end{array}$ & $\begin{array}{l}\text { In the COVID-19 epidemic, the incidence of anxiety } \\
\text { and stress disorder is high among medical staff. } \\
\text { Medical institutions should strengthen the medical } \\
\text { staff's psychological skills training. Special attention } \\
\text { should be paid to the mental health of nurses. }\end{array}$ \\
\hline $\begin{array}{l}\text { LAl, J. et al. } \\
2020\end{array}$ & $\begin{array}{l}\text { Factors } \\
\text { Associated With } \\
\text { Mental Health } \\
\text { Outcomes } \\
\text { Among Health } \\
\text { Care Workers } \\
\text { Exposed r to } \\
\text { Coronavirus } \\
\text { Disease 2019. }\end{array}$ & $\begin{array}{l}\text { Cross-sectional } \\
\text { study, stratified by } \\
\text { region, demographic } \\
\text { data and mental } \\
\text { health } \\
\text { measurements were } \\
\text { collected from } 1,257 \\
\text { health professionals } \\
\text { in } 34 \text { hospitals in } \\
\text { China. }\end{array}$ & $\begin{array}{l}\text { A considerable proportion of health professionals } \\
\text { reported symptoms of depression, anxiety, insomnia, } \\
\text { and distress, especially women, nurses, front-line } \\
\text { health-care workers involved in the diagnosis, } \\
\text { treatment or provision of nursing care to patients with } \\
\text { suspected or confirmed COVID - } 19 \text {. }\end{array}$ \\
\hline $\begin{array}{l}\text { LU, W. } \\
\text { WANG, H. } \\
\text { LIN, W. LI, L. } \\
2020\end{array}$ & $\begin{array}{l}\text { Psychological } \\
\text { status of medical } \\
\text { workforce during } \\
\text { the COVID-19 } \\
\text { pandemic: } \\
\text { cross-sectional } \\
\text { study. }\end{array}$ & $\begin{array}{l}\text { Cross-sectional } \\
\text { survey of a medical } \\
\text { center using online } \\
\text { questionnaires. }\end{array}$ & $\begin{array}{l}\text { The authors report that compared to the non-clinical } \\
\text { team, the front-line medical team with close contact } \\
\text { with infected patients, including working in the } \\
\text { respiratory, emergency, infectious and ICU } \\
\text { departments, had higher scores on the fear scale, } \\
\text { HAMA and HAMD, and was } 1.4 \text { times more likely to } \\
\text { experience fear, twice as likely to experience anxiety } \\
\text { and depression. }\end{array}$ \\
\hline
\end{tabular}




\begin{tabular}{|l|l|l|l|}
\hline $\begin{array}{l}\text { XU, J. et al. } \\
2020\end{array}$ & $\begin{array}{l}\text { Psychological } \\
\text { status of surgical } \\
\text { staff during the } \\
\text { COVID-19 } \\
\text { outbreak. }\end{array}$ & Case-control. & $\begin{array}{l}\text { The results showed, using 4 (four) scales applied to } \\
\text { two groups of health professionals, that the levels of } \\
\text { anxiety and depression of the surgical team during } \\
\text { the period of the outbreak were significantly higher in } \\
\text { the period of the pandemic, deserving psychological } \\
\text { interventions. }\end{array}$ \\
\hline $\begin{array}{l}\text { ANMELLA, } \\
\text { G. et al. 2020 }\end{array}$ & $\begin{array}{l}\text { Unravelling } \\
\text { potential severe } \\
\text { psychiatric } \\
\text { repercussions on } \\
\text { healthcare } \\
\text { professionals } \\
\text { during the } \\
\text { COVID-19 crisis. }\end{array}$ & $\begin{array}{l}\text { Section: } \\
\text { correspondence. } \\
\text { Design: clinical case. }\end{array}$ & $\begin{array}{l}\text { The authors report the case of a general practitioner } \\
\text { with no psychiatric history who developed } \\
\text { psychomotor agitation and psychotic flare reactive to } \\
\text { circumstances related to Covid-19. }\end{array}$ \\
\hline
\end{tabular}

Among the mental health problems found, the presence of vicarious trauma was identified, which is the phenomenon in which health professionals experience symptoms like those of patients, due to continuous exposure. Indirect trauma, common during major catastrophes, has also been observed, manifesting by loss of appetite, fatigue, physical decline, sleep and attention disorders, irritability, numbness, fear and despair ( $F$. Ornell et al., 2020; Schmidt et al., 2020).

Several factors potentially generating psychological distress related to coping with the pandemic were identified, among them, uncertainty about the duration of the crisis, lack of proven therapies or vaccine and potential shortage of health resources, including personal protective equipment (El-Hage et al., 2020; Wu et al., 2020).

Health professionals were also distressed by the effects of social distancing regarding the desire to be present with their families and the possibility of transmitting the disease to friends and family (El-Hage et al., 2020; Wu et al., 2020).

In addition, direct exposure to affected patients, the risk of contagion, the subjectively negative perception of the medical condition and the fact that they are isolated or quarantined represented risk factors for the occurrence of mental symptoms (Röhr et al., 2020).

There is also the presence of another form of psychological suffering, injury or moral damage, where the professional has negative thoughts about himself or about others, such as intense feelings of shame, guilt or disgust (Chen et al., 2020; Greenberg et al., 2020).

Organizational and structural factors have also been described, such as the depletion of personal protective equipment, the lack of specific medications, concerns about the impossibility of providing competent care if implanted in a new area, the lack of access to updated information and communications, the concern with the rapid 
change of information and the shortage of ventilators and beds in intensive care units needed to care for critically ill patients (El-Hage et al., 2020).

\section{Discussion}

During the pandemic, the world experiences a slowdown in daily activities and people are encouraged to practice social distancing in order to reduce contact between individuals, consequently reducing new infections, however, health professionals go in the opposite direction (Vasconcelos et al., 2020).

Due to the exceptional increase in demand for health services, these professionals have been facing long and intense work shifts, often with lack of resources, inappropriate infrastructure and the need to use personal protective equipment (PPE) that is generally rationed and also cause physical discomfort (Miranda et al., 2020; Soares et al., 2020). This problem has a direct impact on the risk of contagion, which rises in direct care for those infected (Helioterio et al., 2020).

According to data from the Federal Nursing Council (Conselho Federal de Enfermagem - COFEN, in Portuguese), about 630 nursing professionals had died from the novel Coronavirus worldwide, and Brazil already totaled 98 of these deaths in early June, surpassing the USA, with then 91 deaths (COFEN, 2020). In Italy, the number of infected professionals reached 4,884 cases, with a total of 24 deaths of doctors registered (Helioterio et al., 2020).

These data reflect the vulnerability of these professionals, who often feel unprepared to perform procedures and clinical interventions for infected patients, due to the continuous change in protocols and treatments, which until the time this article was produced were not well established (Miranda et al., 2020; Felipe Ornell et al., 2020).

Poor working conditions, lack of resources and materials, as well as problems in the flow and organization of the service imply high workloads, increased working hours and privation of breaks and rests (HELIOTERIO et al., 2020). Difficulties intensified in a crisis scenario and which are constantly pointed out in health services as factors that reduce work capacity and generate psychological problems in health professionals (Brooks et al., 2020; Helioterio et al., 2020).

The implications for mental health as a result of the new Coronavirus pandemic are still poorly studied, as it is a recent event, but indicate serious negative impacts. The psychological effects of this pandemic on health professionals cannot be underestimated.

Previous research carried out during other pandemics and infectious outbreaks, such as Ebola, HIV, Zika and H1N1, has shown disruptive developments of the usual, in 
medium and long term, for health professionals and the general population (Felipe Ornell et al., 2020; Powell \& Field, 2007).

An example to be cited happened in the Ebola epidemic in 1995, when survivors revealed a constant fear of dying, of contaminating other people, of abandonment in family relationships and in the cycle of friendships, as well as fearing social stigmatization. Health workers also mentioned fear of causing their own infection, in addition to reporting fear of dying and transmitting the disease to their families. Many expressed feelings of worthlessness, distress for being away from their homes and stress (Schmidt et al, 2020).

Fear can be considered a way to defend yourself in times of stress or danger. It is essential to prepare the human organism, making it stronger and more vigilant. However, when this fear becomes chronic or exaggerated, it can compromise psychological health, resulting in possible psychiatric disorders (Ornell et al., 2020).

Family support is protective against occupational stress, but the professional is afraid of relating and infecting a family member and the experience of social isolation, interpersonal distance are also two factors that have negative psychological impacts on the health professional (Gavin et al., 2020)

A study assessed psychological status by comparing the average values of fear, anxiety and depression between two groups, the medical staff and the administrative staff of a hospital, using an online questionnaire. From 2299 participants, 2042 were from the medical team and 257 from the administrative team. The intensity of symptoms between the teams was significantly different between the two groups, where the team that was in close contact with infected patients had even higher scores, making them more susceptible to psychological disorders (Lu et al., 2020).

Exposure to large-scale deaths, as well as disappointment at not being able to save all lives and even pressures, threats and aggressions from patients who are unable to obtain assistance due to a deficit in physical and material resources, or due to other factors, further expose health professionals to mental illness, making them increasingly anxious and vulnerable to other pathologies (Ornell et al., 2020; Taylor, 2019).

A study carried out in China showed that many health professionals who work on the front line in the fight against the Coronavirus presented important data related to mental health. In a total of 1257 professionals from 34 hospitals (61\% nurses and 39\% doctors), about $50 \%$ suffered from symptoms of depression, $45 \%$ anxiety, $34 \%$ insomnia and $72 \%$ distress. Excessive workload, discrimination and isolation were identified as aggravating psychological distress, leaving these workers more vulnerable to the effects 
of physical and psychological exhaustion in association with fear, emotional disorders and sleep problems (Saidel et al., 2020).

Research fulfilled in Germany identified aggravating factors associated with professionals, being: fear of the risk of infecting themselves and others; not having a clear diagnosis, due to the fact that the symptoms of COVID-19 resemble those of other diseases; having contact with family members; in addition to the concern with physical and mental health, especially in the case of professionals who had a pre-existing mental disorder (Petzold et al, 2020).

The overload of care offered to patients diagnosed with COVID-19 also emerges as a factor capable of leading teams to exhaustion, causing physical and mental exhaustion. Health professionals infected with the virus can feel helplessness, despair, hopelessness, in addition to suffering the consequences of isolation. This scenario brings losses to the mental health of these individuals, requiring protective measures to be taken and urgent effective interventions to promote the mental health of these professionals (Schmidt. B. et al., 2020).

The severity of the pandemic can trigger emotional exhaustion in professionals who work with infected patients. A study reports an increased risk of developing posttraumatic stress disorder (PTSD), also seen after the end of the pandemic. This can occur due to continuous exposure and with symptoms of sleep disturbance, irritability, loss of appetite, fatigue, fear, among others (Li et al., 2020).

It is inevitable that health professionals, who are working on the front line, are more vulnerable to developing emotional problems, because, besides, they also deal with their feelings of failure, helplessness, stress, uncertainties about the new disease, regarding to treatment and the difficulty of overcoming contact with loss of their patients (Miranda, et al, 2020).

It is worth noting the possibility and the need for health professionals to observe signs that the pandemic may have intensified or produced a mental illness scenario. The evidence is expressed through persistence of symptoms, as well as the intensity of suffering, complications in social and daily functioning, increased family or social conflicts, or even suicidal ideas, among other manifestations of psychological distress (Brasil, 2020b).

The WHO recommends the adoption of care for the management of mental illness and psychosocial suffering in health professionals in times of pandemic. Among the recommendations, the following stand out: (1) self-care, (2) seeking support from contact with a trusted colleague or even a family member, (3) recognition and identification of 
their own feelings, (4) rescue of strategies used to overcome adversity in other times of crisis and emergency in health (WHO, 2020).

Notwithstanding the official publication mentioned, the efforts of public health authorities during epidemics have reaching an understanding of the physical and biological effects that the disease can have, with little emphasis on mental health. Thus, we cannot minimize the psychological consequences that this scenario has caused on health professionals. In addition to the various complications that surround the process of coping and controlling a pandemic outbreak, it is necessary to ensure that health professionals have adequate mental health care, including actions aiming to reduce the mental suffering throughout this public health problem (Faro et al., 2020).

In view of the evidence previously described, the negative impact of the pandemic on the mental health of health professionals is verified, directly influencing feelings such as fear, stress and others, which can trigger or aggravate mental disorders such as depressive and anxiety disorders (El-Hage et al., 2020; Huang et al., 2020; Lu et al., 2020; Neto et al., 2020; Xu et al., 2020).

\section{Final Considerations}

It is a consensus in the literature that, faced with this serious public health problem, health professionals can trigger or intensify important psychological symptoms because they are more vulnerable due to the difficulties experienced in their work.

Several studies report on methods used to improve the mental health of health professionals, report that there are several strategies for mental health care but report the importance of assertively implementing these actions.

Organization management attention should be done to assist professionals with the implementation of psychological intervention services. Strong leadership with clear, honest and open communication is needed to make up for fears and uncertainties, supporting mental health will increase individual self-efficacy and confidence, emphasizing altruism to work in health care and serving the greater good will help health professionals to be reminded of their purpose in times of crisis.

Thus, the key role of employing institutions that should be concerned with the health working class and offer psychological care and support is highlighted, in addition to valuing these professionals through a dignified infrastructure, with PPE and recognition for their work.

\section{References}

Brasil. (2020). Coronavírus Brasil. Ministério Da Saúde. 
Brooks, S. K., Webster, R. K., Smith, L. E., Woodland, L., Wessely, S., Greenberg, N., \& Rubin, G. J. (2020). The psychological impact of quarantine and how to reduce it: rapid review of the evidence. In The Lancet (Vol. 395, Issue 10227, pp. 912-920). Lancet Publishing Group. https://doi.org/10.1016/S0140-6736(20)30460-8

Bruna-romero, O., \& Carciofi, B. A. M. (2020). Estimativa da subnotificação de casos da covid-19 no estado de santa catarina. Universidade Federal de Santa Catarina, 1-8.

Chen, Q., Liang, M., Li, Y., Guo, J., Fei, D., Wang, L., He, L., Sheng, C., Cai, Y., Li, X., Wang, J., \& Zhang, Z. (2020). Mental health care for medical staff in China during the COVID19 outbreak. In The Lancet Psychiatry (Vol. 7, Issue 4, pp. e15-e16). Elsevier Ltd. https://doi.org/10.1016/S2215-0366(20)30078-X

El-Hage, W., Hingray, C., Lemogne, C., Yrondi, A., Brunault, P., Bienvenu, T., Etain, B., Paquet, C., Gohier, B., Bennabi, D., Birmes, P., Sauvaget, A., Fakra, E., Prieto, N., Bulteau, S., Vidailhert, P., Camus, V., Leboyer, M., Krebs, M. O., \& Aouizerate, B. (2020). Health professionals facing the coronavirus disease 2019 (COVID-19) pandemic: What are the mental health risks? Encephale, 46 (3S). https://doi.org/10.1016/j.encep.2020.04.008

Faro, A., Bahiano, M. de A., Nakano, T. de C., Reis, C., Silva, B. F. P. da, \& Vitti, L. S. (2020). COVID-19 e saúde mental: a emergência do cuidado. Estudos de Psicologia (Campinas), 37. https://doi.org/10.1590/1982-0275202037e200074

Gavin, B., Hayden, J., Adamis, D., \& Mcnicholas, F. (2020). Caring for the Psychological Well-Being of Healthcare Professionals in the Covid-19 Pandemic Crisis. Irish Medical Journal, 113(4), 53.

Greenberg, N., Docherty, M., Gnanapragasam, S., \& Wessely, S. (2020). Managing mental health challenges faced by healthcare workers during covid-19 pandemic. In The $B M J$ (Vol. 368). BMJ Publishing Group. https://doi.org/10.1136/bmj.m1211

Helioterio, M. C., Lopes, F. Q. R. de S., Sousa, C. C. de, Souza, F. de O., Freitas, P. de S. P., Sousa, F. N. e F. de, \& Araújo, T. M. de. (2020). COVID-19: why is health protection for health workers a priority in combating the pandemic? Scientific Electronic Library Online, 1-18.

Holanda, V. N. (2020). PANDEMIA DE COVID-19 E OS ESFORÇOS DA CIÊNCIA PARA COMBATER O NOVO CORONAVÍRUS. Revista Interfaces: Saúde, Humanas e Tecnologia, 8(1), 360-361. https://doi.org/10.16891/748

Huang, J. Z., Han, M. F., Luo, T. D., Ren, A. K., \& Zhou, X. P. (2020). Mental health survey of medical staff in a tertiary infectious disease hospital for COVID-19. Zhonghua Lao Dong Wei Sheng Zhi Ye Bing Za Zhi = Zhonghua Laodong Weisheng Zhiyebing Zazhi = Chinese Journal of Industrial Hygiene and Occupational Diseases, 38(3), 192-195. https://doi.org/10.3760/cma.j.cn121094-20200219-00063

Li, Z., Ge, J., Yang, M., Feng, J., Qiao, M., Jiang, R., Bi, J., Zhan, G., Xu, X., Wnag, L., Zhou, Q., Zhou, C., Pan, Y., Liu, S., Zhang, H., Yang, J., Zhu, B., Hu, Y., Hashimoto, K., ... Yang, C. (2020). Vicarious traumatization in the general public, members, and non-members of medical teams aiding in COVID-19 control. Brain, Behavior, and Immunity, 20. https://doi.org/10.1016/j.bbi.2020.03.007

Lu, W., Wang, H., Lin, Y., \& Li, L. (2020). Psychological status of medical workforce during the COVID-19 pandemic: A cross-sectional study. Psychiatry Research, 288, 1-5. https://doi.org/10.1016/j.psychres.2020.112936

Miranda, F. M. D., Santana, L. de L., Pizzolato, A. C., \& Sarquis, L. M. M. (2020). CONDIÇÕES DE TRABALHO E O IMPACTO NA SAÚDE DOS PROFISSIONAIS DE ENFERMAGEM 
FRENTE A COVID-19. Cogitare Enfermagem, 25(0). https://doi.org/10.5380/CE.V25I0.72702

Neto, M. L. R., Almeida, H. G., Esmeraldo, J. D., Nobre, C. B., Pinheiro, W. R., Oliveira, C. R. T., Sousa, I. C., Lima, O. M. M. L., Lima, N. N. R., Moreira, M. M., Lima, C. K. T., Júnior, J. G., \& Silva, C. G. L. (2020). When health professionals look death in the eye: the mental health of professionals who deal daily with the 2019 coronavirus outbreak. Psychiatry Research, 288. https://doi.org/10.1016/j.psychres.2020.112972

Ornell, F., Halpern, S. C., Kessler, F. H. P., \& Narvaez, J. C. M. (2020). The impact of the COVID-19 pandemic on the mental health of healthcare professionals. Cadernos de Saúde Pública, 36(4), 1-6. https://www.scielo.br/pdf/csp/v36n4/1678-4464-csp-3604-e00063520.pdf

Ornell, Felipe, Schuch, J. B., Sordi, A. O., \& Kessler, F. H. P. (2020). "Pandemic fear" and COVID-19: mental health burden and strategies. Revista Brasileira de Psiquiatria (Sao Paulo, Brazil: 1999), 42(3), 232-235. https://doi.org/10.1590/1516-4446-20200008

Powell, H., \& Field, M. (2007). Stress increases attentional bias for alcohol cues in social drinkers who drink to cope. Alcohol and Alcoholism, 42(6), 560-566. https://doi.org/10.1093/ALCALC

Röhr, S., Müller, F., Jung, F., Apfelbacher, C., Seidler, A., \& Rieldel-Heller, S. L. (2020). Psychosocial Impact of Quarantine Measures during Serious Coronavirus Outbreaks: A Rapid Review. Psychiatrische Praxis, 47(4), 179-189. https://doi.org/10.1055/a1159-5562

Saidel, M. G. B., Lima, M. H. M., Campos, C. J. G., Loyola, C. M. D., Esperidião, E., \& Rodriques, J. (2020). Intervenções em saúde mental para profissionais de saúde frente a pandemia de Coronavírus. Rev Enferm UERJ, 28(49923).

Schimit, B., CREPALDI, M. A., BOLZE, S. D. A., NEIVA-SILVA, L., \& DEMENECH, L. M. (2020). Saúde mental e intervenções psicológicas diante da pandemia do novo coronavírus (COVID-19). Estudos de Psicologia (Campinas), 37. https://doi.org/10.1590/1982$0275202037 \mathrm{e} 200063$

Schmidt. B., Crepaldi, M. A., Bolze, S. D. A., Silva, L. N., \& Demenech, L. M. (2020). Saúde mental e intervenções psicológicas diante da pandemia do novo coronavírus $\begin{array}{lllll}\text { (COVID-19). Estudos de Psicologia } & \text { 37, }\end{array}$ https://www.scielo.br/pdf/estpsi/v37/1678-9865-estpsi-37-e200063.pdf

Vasconcelos, C. S. da S., Feitosa, I. D. O., Medrado, P. L. R., \& Brito, A. P. B. de. (2020). O Novo Coronavírus e os impactos psicológicos da quarentena. DESAFIOS - Revista Interdisciplinar Da Universidade Federal Do Tocantins, 7(Especial-3), 75-80. https://doi.org/10.20873/uftsuple2020-8816

WHO. (2020). Mental health and psychosocial considerations during the COVID-19 outbreak. In World Health Organization (WHO) (pp. 01-06).

Wu, P. E., STYRA, R., \& GOLD, W. L. (2020). Mitigating the psychological effects of COVID19 on health care workers. CMAJ, 192(17), 460. https://doi.org/10.1503/cmaj.200519

Xu, J., Xu, Q. H., Wang, C. M., \& Wang, J. (2020). Psychological status of surgical staff during the COVID-19 outbreak. Psychiatry Research, 288. https://doi.org/10.1016/j.psychres.2020.112955

Zhou, F., Yu, T., Du, R., Fan, G., Liu, Y., Liu, Z., Xiang, J., Wang, Y., Song, B., Gu, X., Guan, L., Wei, Y., Li, H., Wu, X., Xu, J., Tu, S., Zhang, Y., Chen, H., \& Cao, B. (2020). Clinical course and risk factors for mortality of adult inpatients with COVID-19 in Wuhan, 
China: a retrospective cohort study. The Lancet, 395(10229), 1054-1062. https://doi.org/10.1016/S0140-6736(20)30566-3

\section{RESUMO:}

A pandemia da doença causada pelo novo Coronavírus - SARS-Cov-2 se caracteriza como um dos maiores problemas de saúde pública internacional das últimas décadas. Este estudo se propôs a realizar uma revisão narrativa das evidências descritas sobre 0 impacto na saúde mental dos profissionais de saúde que atuam na prática assistencial relacionada à Covid-19. Os artigos evidenciaram que os problemas enfrentados pelos profissionais de saúde durante a pandemia podem levar à exaustão da equipe, esgotamento físico e mental contribuindo para o desenvolvimento de problemas psicológicos.

PALAVRAS-CHAVE: Covid-19; Saúde Mental; Profissionais de saúde.

\section{RESUMEN:}

La pandemia de enfermedad causada por el nuevo coronavirus - SARS-Cov-2 se caracteriza por ser uno de los mayores problemas de salud pública internacional en las últimas décadas. Este estudio tuvo como objetivo realizar una revisión narrativa de la evidencia descrita sobre el impacto en la salud mental de los profesionales de la salud que trabajan en la práctica asistencial relacionada con Covid-19. Los artículos mostraron que los problemas que enfrentan los profesionales de la salud durante la pandemia pueden llevar al agotamiento del equipo, al agotamiento físico y mental, contribuyendo al desarrollo de problemas psicológicos.

PALABRAS-CLAVES: COVID-19; Salud mental; Profesionales de la salud. 